Research Journal of Biological Sciences 7 (2): 97-101, 2012

ISSN: $1815-8846$

(C) Medwell Journals, 2012

\title{
Two New Oxynoemacheilus (Teleostei: Nemacheilidae) Species from Western Turkey
}

\author{
Fusun Erk'akan \\ Department of Biology, Faculty of Science, Hacettepe University, \\ Beytepe Campus, 06800 Ankara, Turkey
}

\begin{abstract}
In this study, Oxynoemacheilus mesudae from Kufu stream, Buyuk Menderes river, Dinar and Oxynoemacheilus atili Eflatun Pinari, Beysehir Lake Basin were described. These two new species are distinguished from the other members of Oxynoemacheilus by the shape of swim bladder bony capsule, colour pattern and some morphometric characteristics.
\end{abstract}

Key words: Oxynoemacheilus mesudae, Oxynoemacheilus atili, new species, swim bladder, bony capsule, Western Turkey

\section{INTRODUCTION}

According to the last study about Western palaearctic loach genus Oxynoemacheilus, 41 species are recognized as valid. Of these, 30 species are living in Anatolia. In this study, two additional new species from Western Turkey were described. Also, molecular studies with cytochrome $b$ and $R A G$ genes of collected specimens supported this study.

\section{MATERIALS AND METHODS}

Specimens were collected from Buyuk Menderes river Basin, Dinar, Civril and Eflatun pinari (Beysehir Lake Basin) by electro-fishing equipment, respectively in June, 2007 and 2010 and preserved 5\% solution of formaldehyde. Eighteen morphometric, 5 meristic characteristics were measured by following Banarescu and Nalbant (1964) and Erk'akan et al. (2007, 2008). Specimens are deposited in HUIC; Hacettepe University, Ichthyological collection.

\section{Comperative material}

Oxynoemacheilus anatolicus: HUIC: AKD, 15 specimens, 38-52 mm SL; Southwest Turkey: Burdur, Ynput of Karamanli Dam Lake; 37²4'34.33' 'N 2949'54.94' 'E; F. Erk'akan.

Oxynoemacheilus cinicus: HUС: BM-3, 23 specimens, 25-59 mm SL; Turkey: Denizli, Cin Stream; $37^{\circ} 40^{\prime} 41.07^{\prime}$ 'N 29³0'13.08' 'E; F. Erk'akan.

Oxynoemacheilus germencicus: HUIC: BM-1, 8 specimens, 40-63 mm SL; Turkey: Aydyn, Germencik 15 th $\mathrm{km} ; 37^{\circ} 38^{\prime} \mathrm{N} 27^{\circ} 28^{\prime}$ E; F. Erk'akan.
Oxynoemacheilus simavicus: HUIC: KM-1, 55 specimens, 27-37 mm SL; Turkey: Aydyn, Odemis; $38^{\circ} 39^{\prime} \mathrm{N} 27^{\circ} 28^{\prime} \mathrm{E}$; F. Erk'akan.

Oxynoemacheilus theophilii: HUIC: KE-1, 17 specimens, 32-54 mm SL; Turkey: Bergama, Kozak (Madra) Creek, $39^{\circ} 40^{\prime} \mathrm{N}, 2^{\circ} 28^{\prime} \mathrm{E} ; \mathrm{F}$. Erk'akan.

Oxynoemacheilus mediterraneus: HUIC: AKD-2a, 8 specimens, 53-67 mm SL; Turkey: Eoirdir, Candyr, Aksu Stream, $37^{\circ} 38^{\prime} \mathrm{N} 30^{\circ} 31^{\prime} \mathrm{E}$; F. Erk'akan. HUIC: AKD-3, 27 specimens, 49-58 mm SL; Turkey: Madenli-Aksu Stream, Eoirdir; F. Erk'akan.

Oxynoemacheilus phoxinoides: HUIC: 712, 10 specimens, 32-52 mm SL; Turkey: Yznik; $40^{\circ} 41^{\prime} \mathrm{N} 29^{\circ} 30^{\prime} \mathrm{E}$; S.C. Ozeren.

Oxynoemacheilus angorae: HUC: SA-19, 50 specimens, 34-63 mm SL; Turkey: Gicik Village, 4004'K $32^{\circ} 52^{\prime} \mathrm{D}$ Ankara; F. Erk'akan.

Oxynoemacheilus eregliensis: HUIC (uncataloged): 26 specimens, 25-61 mm SL. Turkey: Ybrala stream, Yesildere, Karaman; 37²12'279' 'N 3324' 173' 'E; F. Erk'akan.

Oxynoemacheilus banarescui: HUIC: BK-5, 18 specimens, 25-53 mm SL, Turkey: Devrek stream, Devrek; $41^{\circ} 11^{\prime} 0842^{\prime}$ 'K $31^{\circ} 55^{\prime}$ 5605' 'D; F. Erk'akan.

Oxynoemacheilus kosswigi: HUIC: KI- 8, 23 specimens, 38-83 mm SL, Turkey: Yildiz stream, Kizilirmak., YildizeliSivas; 3952' 2441' 'K 3648' 5418' ' D; F. Erk'akan. 


\section{RESULTS AND DISCUSSION}

\section{Oxynoemacheilus mesudae $\boldsymbol{n}$ sp.}

Holotype: About $60.8 \mathrm{~mm}$ SL, Buyuk Menderes river, Dinar, Civril, 38 $07^{\prime} 366^{\prime}$ 'N 30'05' 723' 'E leg. F. Erk' akan and F. Ozdemir, coll F. Erk'akan (June et al., 2007).

Paratypes: HUIC, 15 specimens, 54.49-71.73 mm SL.

Diagnosis: Oxynoemacheilus mesudae is an angorae group species and distinguished from all other angorae group species of Oxynoemacheilus in Turkey by its shape of bony capsule of swim bladder, colour pattern and some body ratios.

Description: General appearance of $O$. mesudae is shown in Fig. 1. Morphometric data of holotype (HUIC, uncataloged specimen) and 15 paratypes (HUIC, uncataloged specimens) are shown in Table 1. Body elongated and moderately stout. Body depth 5.8-7.2 times in the standard length. Lateral line complete. Head pointed.

Head depth is 1.96-2.08 times in head length. Eyes are upper position and 5.6-6.8 times in head length. Anterior nare prolonged in a short tube, posterior nasal opening oval. Mouth arched and lips and barbels are papillated, lips furrowed, lower lip has small incision (Fig. 2c) and upper lip with a median notch. Prosessus dentiformis weakly to medium developed. Pectorals are papillated and longer in males. Dorsal fin with 3 simple and $7^{1 / 2}$ branched rays, anal fin with two simple and $5^{1 / 2}, 6$ branched rays. Upper margin of dorsal fin strait but anal fin convex. Dorsal fin length is greater than its base length. Pectoral fin with 11 rays. Pelvic axillary lobe present and pelvic fin with 8 rays and reaching midway to anal fin origin but in some samples reaching anus. Caudal fin with $8+8$ branched principal rays and slightly forked, lobes rounded. There are low and short dorsal and ventral adipose crests on posterior part of caudal peduncle. Body covered with scales with small excentric focal zone. The shape of digestive track and bony swim-bladder capsule are shown in Fig 2a, b.

Sexual dimorfizm: Suborbital flap is present in males and pectoral fins are more longer in males than females.

Colouration: In fresh material, dorsal posterior part of the body with regular big black spots. Black line extending in

Table 1: Morphometric characteristics of 0. mesudae $n \mathrm{sp}$.

\begin{tabular}{|c|c|c|c|c|}
\hline \multirow[b]{2}{*}{ Morphometric characters } & \multicolumn{4}{|c|}{ O. mesudae $(\mathrm{n}=16)$} \\
\hline & Min. & Max. & Ort & SD \\
\hline Standart length (mm) & 54.49 & 71.73 & & \\
\hline \multicolumn{5}{|l|}{ SL $(\%)$} \\
\hline Head length & 22.48 & 25.71 & 24.16 & 0.90 \\
\hline Pre-dorsal length & 48.31 & 51.01 & 49.42 & 0.93 \\
\hline Pre-pelvic length & 49.16 & 52.29 & 50.88 & 0.90 \\
\hline Pre-anal length & 69.78 & 72.86 & 71.38 & 0.87 \\
\hline Body width & 10.08 & 13.44 & 11.08 & 0.83 \\
\hline Body depth & 14.23 & 16.97 & 15.38 & 0.84 \\
\hline Caudal peduncle depth & 08.51 & 10.79 & 09.66 & 0.67 \\
\hline Caudal peduncle length & 15.05 & 17.44 & 16.28 & 0.89 \\
\hline Dorsal fin base length & 10.63 & 13.94 & 12.16 & 0.94 \\
\hline Dorsal fin last simple length & 14.39 & 17.11 & 15.86 & 0.84 \\
\hline Anal fin depth & 13.96 & 17.83 & 15.79 & 0.93 \\
\hline Pelvic fin length & 14.25 & 17.09 & 15.82 & 0.93 \\
\hline Pectoral fin length & 18.13 & 20.79 & 19.16 & 0.86 \\
\hline \multicolumn{5}{|l|}{ Head length $(\%)$} \\
\hline Head depth & 48.04 & 50.79 & 49.45 & 0.91 \\
\hline Eye diameter & 14.70 & 17.75 & 16.41 & 0.88 \\
\hline Snouth length & 38.23 & 40.88 & 39.30 & 0.90 \\
\hline Interorbital length & 23.14 & 26.66 & 24.81 & 0.93 \\
\hline
\end{tabular}

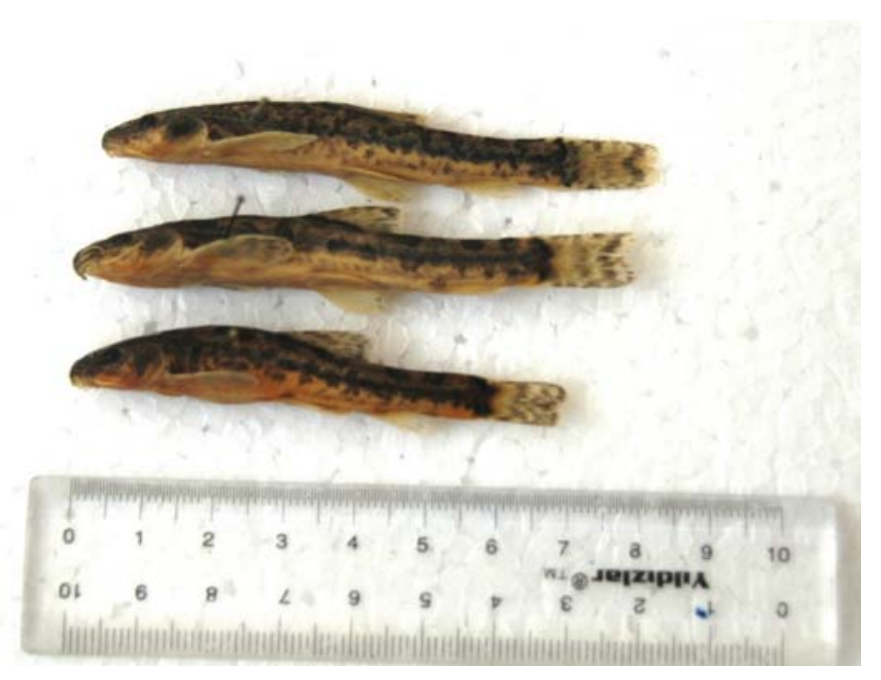

Fig. 1: General appearance of $O$. mesudae $n \mathrm{sp}$. 


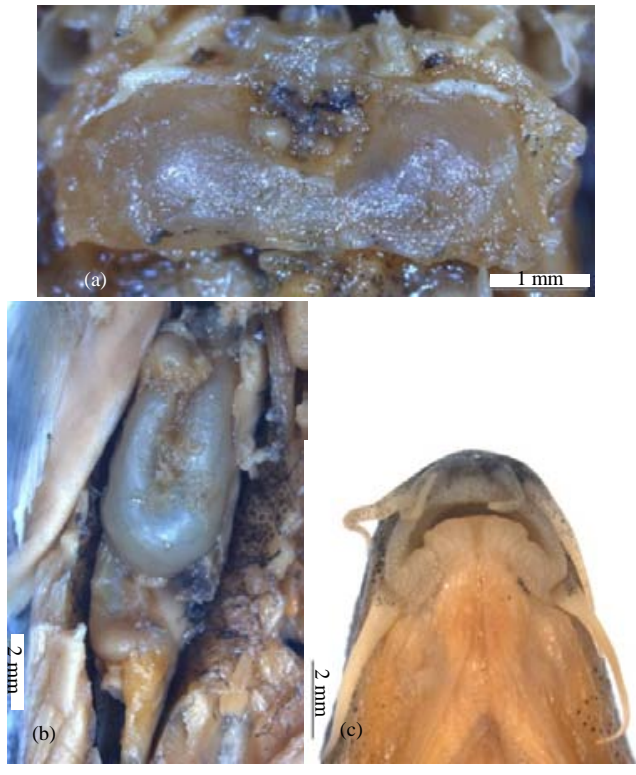

Fig. 2: O. mesudae $n$ sp.: a) Bonny swim bladder capsule; b) Digestive tract; c) Mouth shape

the latero-median side of the body and moderately big black spots on the flank. Caudal fin with three regular black bars and dorsal and pectoral fins with irregular black spots.

Etymology: Named for Mesude Kaynak, my mother.

Distribution: Buyuk Menderes river and Isikli Lake. This new species may be found in Kucuk Menderes and Gediz rivers (Western Anatolia).

Remarks: Oxynoemacheilus mesudae differs from its closely related species (unpublished MS with Perdices and Freyhof) Oxynoemacheilus germencicus (Erk'akan et al., 2007) by its shape of bony swim-bladder capsule, digestive track and some morphometric data (Erk'akan et al., 2007). O. mesudae is also similiar to $O$. angorae group living in central and western Anatolia: $O$. angorae, $O$. anatolica, $O$. eregliensis and $O$. atili $n \mathrm{sp}$. but is easily distinguished from all members of this group by its colour pattern (Stoumboudi et al., 2006) in fresh material. Oxynoemacheilus mesudae differs from O. angorae by prepelvic length $49-52 \%$ in SL (vs. 72.5), body depth $14-17 \%$ in SL (vs. 18), caudal peduncle depth $8,5-10,8 \%$ in SL (vs. 11), head depth $48-51 \%$ in $\mathrm{HL}$ (vs. 56), eye diameter $14.7-18 \%$ in $\mathrm{HL}$ (vs. 20.7), interorbital length $23-27 \%$ in HL (vs. 29) and shape of swim-bladder capsule and digestive track (Erk'akan et al., 2007).
Table 2: Morphometric characteristics of $O$. atili $n \mathrm{sp}$.

\begin{tabular}{|c|c|c|c|c|}
\hline \multirow[b]{2}{*}{ Morphometric Characters } & \multicolumn{4}{|c|}{ O. atili $(\mathrm{n}=34)$} \\
\hline & Min & $\operatorname{Max}$ & Ort & $\mathrm{SD}$ \\
\hline Standart length(mm) & 33,75 & 75.63 & & \\
\hline \multicolumn{5}{|l|}{ SL $(\%)$} \\
\hline Head length & 23.10 & 26.26 & 24.57 & 0.88 \\
\hline Pre-dorsal length & 47.26 & 50.44 & 48.70 & 0.91 \\
\hline Pre-pelvic length & 48.09 & 51.44 & 49.88 & 0.86 \\
\hline Pre-anal length & 70.08 & 73.63 & 71.79 & 0.87 \\
\hline Body width & 12.10 & 15.53 & 13.73 & 0.94 \\
\hline Body depth & 17.01 & 21.23 & 18.25 & 0.92 \\
\hline Caudal peduncle depth & 07.07 & 10.94 & 09.13 & 0.90 \\
\hline Caudal peduncle length & 16.24 & 20.37 & 17.64 & 0.88 \\
\hline Dorsal fin base length & 10.53 & 13.93 & 12.25 & 0.93 \\
\hline Dorsal fin last simple length & 13.97 & 17.02 & 15.50 & 0.93 \\
\hline Anal fin depth & 12.43 & 16.56 & 14.70 & 0.93 \\
\hline Pelvic fin length & 13.99 & 18.06 & 16.07 & 0.94 \\
\hline Pectoral fin length & 17.56 & 20.82 & 19.14 & 0.94 \\
\hline \multicolumn{5}{|l|}{ Head length (\%) } \\
\hline Head depth & 56.49 & 59.76 & 58.09 & 0.88 \\
\hline Eye diameter & 19.32 & 22.82 & 21.23 & 0.92 \\
\hline Snouth length & 37.32 & 40.11 & 38.67 & 0.92 \\
\hline Interorbital length & 28.57 & 31.76 & 29.97 & 0.89 \\
\hline
\end{tabular}

O. mesudae differs from $O$. anatolica by its colour pattern shape of swim-bladder bony capsule and dorsal fin with 8 (vs. 5-7) branched rays and pectorals with 11 rays (vs. 10) (Erk'akan et al., 2008). Also preanal length $70-71 \%$ in SL (vs. 69\%), head depth $48-51 \%$ in $\mathrm{HL}$ (vs. $53 \%$ ) and interorbital length $23-27 \%$ in $\mathrm{HL}$ (vs. 30\%) (Erkakan et al., 2008).

$O$. mesudae differs from $O$. eregliensis by the shape of swim-bladder bony capsule, its colour pattern and some body ratios such as predorsal length $48-51 \%$ in SL (vs. 45\%), preanal length $70-73 \%$ in SL (vs.68\%), caudal preduncle length $9-11 \%$ in SL (vs. 8\%), head depth $48-51 \%$ in $\mathrm{HL}$ (vs. $42 \%$ ) and interorbital length $23-27 \%$ in HL (vs. 28) (Erk'akan et al., 2007).

$O$. mesudae differs from $O$. phoxinoides by predorsal length $48-51 \%$ in SL (vs. 44), caudal peduncle length $15-17 \%$ in SL (vs. 14), preanal length $70-73 \%$ in SL (vs. 68), interorbital length $233-26 \%$ in $\mathrm{HL}$ (vs. 30 ). It is also easily distinguished from $O$. phoxinoides by its colour pattern and the presence of sub-orbital flap (Erk'akan et al., 2007). $O$. mesudae differs from another new species $O$. atili, described in this M.S., by the shape of bony capsule of swim-bladder, digestive track mouth structure and colour pattern (Fig. 1, 2). Also, it differs from $O$. atili $n$ sp. with body width $10-13 \%$ in SL (vs. 14\%), body depth 14-17\% in SL (vs. 18\%), head depth $48-51 \%$ in HL (vs 58\%) and interorbital length $23-27 \%$ in HL (vs. $30 \%$ ) (Table 1 and 2).

\section{Oxynoemacheilus atili $\boldsymbol{n}$ sp.}

Holotype: About $72.3 \mathrm{~mm}$ male, HUIC, uncataloged specimen, Eflatun pinari-Beysehir Lake, Turkey $37^{\circ} 49^{\prime}$ $30.95^{\prime}$ ' K, 31 $40^{\prime} 29.08^{\prime}$ ' D, leg and coll. F. Erk'akan.

Paratypes: HUIC, 33 uncataloged specimens, 33.75$75.63 \mathrm{~mm}$ SL. 


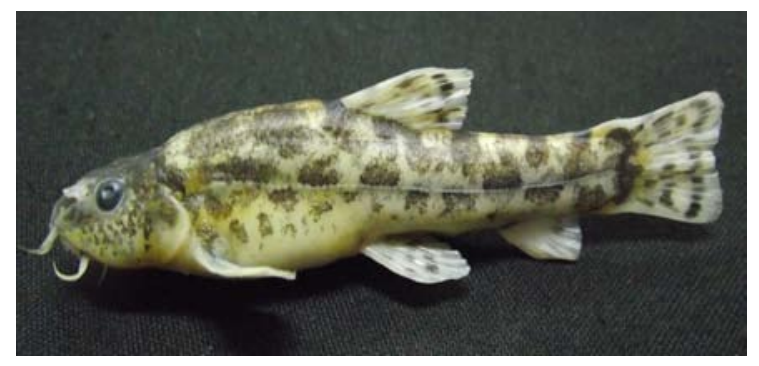

Fig. 3: General appearance of $O$. atili $n \mathrm{sp}$.

Diagnosis: Oxynoemacheilus atili is distinguished from all other species of Oxynoemacheilus in Turkey by its colour pattern, shape of the bony capsule of the swim-bladder, scales present only the posterior part of the body and embedded in the skin and some body ratios.

Description: General appearance of $O$. atili is shown in Fig. 3. Morphometric data of holotype and 33 paratypes are shown in Table 2. Body elongated and moderately stout. Body depth 4.7-5.8 (5.4) times in standard length. Lateral line complete but in some specimens, it is ended close to the the base of the caudal peduncle. No axillary pelvic lobe. Mouth large, upper lip with median notch. Lips fleshy and not papillated (Fig. 4c). Prosessus dentiformis weakly to median developed. Suborbital flap can be seen as a shallow groove. Head depressed, head depth 1.96-2.1 (2.02) times in head length. Nostrils much nearer to eye than tip of snout and anterior nostril pierced in front side of a long tube. Eyes in upper position and eye diameter 5.6-6.8 (6.0) times in head length. No scales anterior part of the body. Posterior part of the body scales are seldom and embedded in the body. The shape of bony swim-bladder capsule and digestive track are shown in Fig. 4a, b. Dorsal fin with 3 simple and $7^{1 / 2}$ branched rays distal margin of dorsal fin straight. Anal fin with 3 simple and $5-5^{1 / 2}$ branched rays. Pelvic fin with 6 rays reaching slightly to anus. Caudal fin with $8+8$ branched principal rays, slightly forked, lobes rounded. Pectoral fin with 9-10 rays, longer in males, reaching the pelvic fin origin. Low dorsal and ventral adipose crests on posterior part of the caudal peduncle. Largest recorded size $75.63 \mathrm{~mm} \mathrm{SL}$.

Sexual dimorphism: In males, pectorals are longer than females and sub-orbital flap with shallow groove.

Colouration: In preserved material, head: dorsal is black and lateral back-ground pale beige with little rounded black spots under eye, big black spot on operculum. Flank: back ground pale beige with big black rounded spots on the body but under lateral line of anterio-lateral
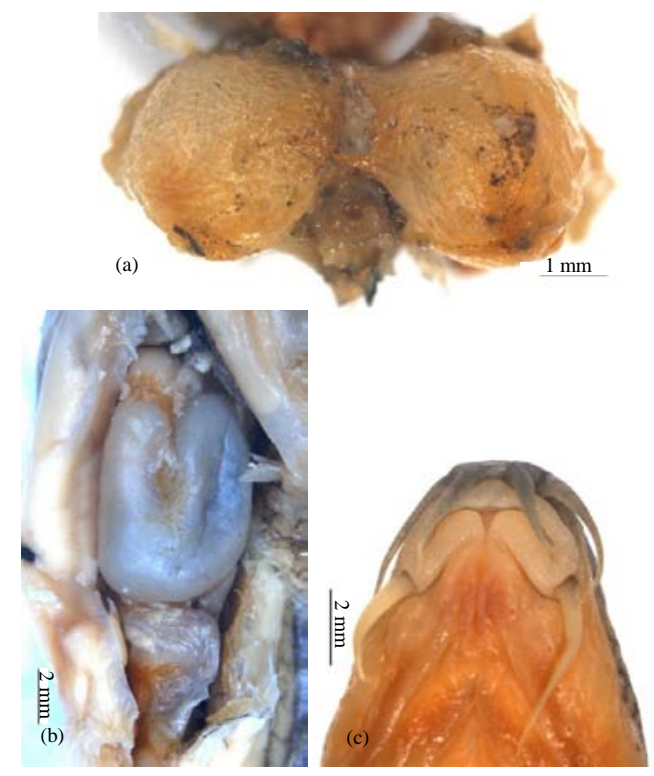

Fig. 4: O. atili $n$ sp.: a) Bonny swim bladder capsule; b) Digestive tract; c) Mouth shape

part with irregular little back spots. Black line markedly on the caudal fin base and caudal fin with 2-3 series of black bars.

Distribution: Known from Eflatun pinari, Beysehir lake.

Etymology: Named for Mr. Ahmet Tuncay Atil.

Remarks: Oxynoemacheilus atili differs from angorae group of other species of Oxynoemacheilus in Western and Cental Turkey with its colour pattern, shape of swim-bladder capsule, digestive track and some body ratios.

Oxynoemacheilus atili easily distinguished from its closely releated species Oxynoemacheilus eregliensis by its colour pattern (Stoumboudi et al., 2006), shape of swim-bladder capsule, predorsal length $47-50 \%$ in SL (vs. $45 \%$ ), caudal peduncle length $16-20 \%$ in SL (vs. 14\%), head depth $48-51 \%$ in head length (vs. 42) (Erk'akan et al., 2007).

Oxynoemacheilus atili differs from $O$. angorae by predorsal length $47-50 \%$ in SL (vs. 51\%), head depth $57-60 \%$ in HL (vs. 56\%), shape of swim-bladder capsule, digestive track and colour pattern (Erk'akan et al., 2007). Oxynoemacheilus atili is distinguished from $O$. anatolica by predorsal length $47-50 \%$ in SL (vs. 51), preanal length $70-74 \%$ in SL (vs. 69), body width $12-16 \%$ in SL (vs. 11), body depth $17-21 \%$ in SL (vs. 15), head depth $57-60 \%$ in HL (vs. 53), eye diameter 19-23\% in HL (vs. 16). Also, it differs by the shape of swim-bladder 
capsule and colour pattern (Erk'akan et al., 2008). Oxynoemacheilus atili differs from by Oxynoemacheilus phoxinoides by the shape of the mouth, bony capsule of swim-bladder, colour pattern and body depth $17-21 \%$ in SL (vs. 16), predorsal length $47-50 \%$ in SL (vs. 44), head depth 57-60\% in HL (vs. 50) (Erk'akan et al., 2007).

\section{CONCLUSION}

Oxynoemacheilus mesudae and $O$. atili also easily distinguished from cinicus, simavicus, germencicus, theophili, banarescui, kosswigi and mediterranus by the angorae shape group of the body, colour pattern and some body ratios (Erk'akan et al., 2011; Stoumboudi et al., 2006).

\section{ACKNOWLEDGEMENTS}

Researcher is pleased to thank Filiz Ozdemir, Ibrahim Aslan and Yagmur Kumser for their help during field research.

\section{REFERENCES}

Banarescu, P. and T.T. Nalbant, 1964. Susswasserfische der Turkei. 2. Teil: Cobitidae. Mitt. aus dem Hamburgischen Zoologischen Museum und Institute, 61: 159-201.

Erk'akan, F., J. Freyhof, S.C. Ozeren and A. Perdices, 2011. An overview of the western Palaearctic loach genus Oxynoemacheilus (Teleostei: Nemacheilidae). Ichthyological Explor. Freshwater, 22: 301-312.

Erk'akan, F., S.C. Ozeren and T.T. Nalbant, 2008. Two new species of stone loaches from Turkey (Teleostei: Nemacheilidae). J. Fish. Int., 3: 115-119.

Erk'akan, F., T.T. Nalbant and S.C. Ozeren, 2007. Seven new species of Barbatula, three new species of Schistura and a new species of Seminemacheilus (Ostariophysi: Balitoridae: Nemacheilinae) from Turkey. J. Fish. Int., 2: 69-85.

Stoumboudi, M.T., M. Kottelat and R. Barbieri, 2006. The fishes of the inland waters of Lesbos Island, Greece. Ichthyological Explor. Freshwater, 17: 129-146. 